\title{
Yumurtacı Tavuk Yemlerine Biberiye (Rosmarinus officinalis L.) Uçucu Yağ İlavesinin Performans, Yumurta Kalite Kriterleri ve Yumurta Sarısı Lipit Oksidasyonu Üzerine Etkisi ${ }^{\#}$
}

\author{
Tülay Çimrin ${ }^{1 *}$, Murat Demirel ${ }^{2}$ \\ ${ }^{1}$ Mustafa Kemal Üniversitesi Ziraat Fakültesi Zootekni Bölümü 31034 Hatay, Türkiye \\ ${ }^{2}$ Yüzüncü Yıl Üniversitesi Ziraat Fakültesi Zootekni Bölümü 65080 Van, Türkiye
}

M A K A L E B İ L G İ S İ

\#Tülay Çimrin'in Doktora Tezinden özetlenmiştir.

Geliş 03 Kasım 2015

Kabul 24 Kasim 2015

Çevrimiçi baskı, ISSN: 2148-127X

Anahtar Kelimeler:

Yumurtacı tavuk

Biberiye uçucu yağ 1

Performans

Yumurta kalite kriterleri

Yumurta sarısı malondialdehit (MDA)

$\overline{\text { * Sorumlu yazar: }}$

Ö Z E T

Bu çalışma, yumurtacı tavuk yemlerine farklı dozlarda biberiye uçucu yağı ilavelerinin performans, yumurta kalite kriterleri, taze ve depolanan yumurta sarısı malondialdehit (MDA) düzeyi üzerindeki etkilerini belirlemek üzere yapılmıştır. Çalışmada, tavuklar tesadüf parselleri deneme desenine göre rastgele 6 gruba ayrılmış ve her bir grup 5 tekerrüre ayrılmıştır. Her tekerrürde 8 tavuk olmak üzere toplam 240 adet, 32 haftalık yaşta Bovans genotipi beyaz yumurtacı tavuk kullanılmıştır. Deneme grupları; Kontrol (Negatif Kontrol), $500 \mathrm{mg} / \mathrm{kg}$ antibiyotik (Pozitif Kontrol 1), $200 \mathrm{mg} / \mathrm{kg}$ vitamin E (Pozitif Kontrol 2), $100 \mathrm{mg} / \mathrm{kg}$ biberiye uçucu yağı, $200 \mathrm{mg} / \mathrm{kg}$ biberiye uçucu yağı ve $300 \mathrm{mg} / \mathrm{kg}$ biberiye uçucu yağı içeren karma yemle oluşturulmuştur. Canlı ağırlık, yumurta verimi, yumurta ağırlığı, hasarlı yumurta oranı, ölüm oranı ve yumurta kalite kriterleri bakımından kontrol ve deneme grupları arasında önemli bir fark bulunmamış fakat yem tüketimi, yemden yararlanma oranı ve yumurta sarısı MDA değerleri önemli düzeyde etkilenmiştir. Negatif kontrol grubuna göre tüm gruplar yem tüketimini düşürmüş $500 \mathrm{mg} / \mathrm{kg}$ antibiyotik ve $100 \mathrm{mg} / \mathrm{kg}$ biberiye dozu hariç diğer dozlar yemden yararlanma oranını önemli düzeyde iyileştirmiştir. Karma yeme $100 \mathrm{mg} / \mathrm{kg}$ biberiye uçucu yăg ilavesi 42 ve 56 günlük depolama süresinde ve $200 \mathrm{mg} / \mathrm{kg}$ vitamin E ilavesi ise tüm depolama sürelerinde yumurta sarısı MDA değerlerini önemli düzeyde düşürmüştür. Sonuç olarak yumurtacı kanatlı karma yemlerinde $200 \mathrm{mg} / \mathrm{kg}$ vitamin E ve $100 \mathrm{mg} / \mathrm{kg}$ biberiye uçucu yağı katkıları lipit oksidasyonunu önlemek için kullanılabilir.

Turkish Journal Of Agriculture - Food Science And Technology, 4(2): 113-119, 2016

\section{The Effects of Dietary Rosemary (Rosmarinus officinalis L.) Essential Oil Supplementation on Laying Hen Performance, Egg Quality and Oxidative Stability of Egg}

\section{A R T I C LE IN F O}

\section{Article history:}

Received 03 November 2015

Accepted 24 November 2015

Available online, ISSN: 2148-127X

\section{Keywords:}

\section{Laying hen}

Rosemary essential oil

Performance

Egg quality

Egg yolk malondialdehyde (MDA)

\footnotetext{
* Corresponding Author:

E-mail: tcimrin@mku.edu.tr
}

\section{A B S T R A C T}

This experiment was designed to investigate the effects of rosemary essential oils in various doses on hen performance, egg quality, lipid peroxidation malondialdehyde (MDA) level in fresh and stored egg yolk. The experiment was carried out in random parcel experimental design. In the experiment, 6 groups were formed and each group was divided into 5 replicates. In total 240 Bovans hite laying hens, each replicate included 8 hens, 32 weeks old, were used. Treatment groups were control (Negative Control), 500 $\mathrm{mg} / / \mathrm{kg}$ antibiotic (Positive Control 1), $200 \mathrm{mg} / \mathrm{kg}$ vitamin E (Positive Control 2), 100 $\mathrm{mg} / \mathrm{kg}$ rosemary essential oil, $200 \mathrm{mg} / \mathrm{kg}$ rosemary essential oil, $300 \mathrm{mg} / \mathrm{kg}$ rosemary essential oil. There was no significant difference in live weight, egg production, egg weight, damaged egg ratio, mortality and egg quality but feed comsumption, feed conversion ratio (FCR) and egg yolk MDA values were affected significantly in between control and treatment groups. At all treatment groups feed comsumption decreased significantly and other groups improved in feed conversion ratio except $500 \mathrm{mg} / \mathrm{kg}$ antibiotic and $100 \mathrm{mg} / \mathrm{kg}$ rosemary doses groups compared to negative control significantly. $100 \mathrm{mg} / \mathrm{kg}$ rosemary essential oil addition during the storage time for 42 and 56 days and $200 \mathrm{mg} / \mathrm{kg}$ vitamin $\mathrm{E}$ addition for all storage time to ration decreased egg yolk MDA values significantly. As a result, laying birds fed $200 \mathrm{mg} / \mathrm{kg}$ vitamin E, and $100 \mathrm{mg} / \mathrm{kg}$ of rosemary essential oil additives can use to prevent lipid oxidation. 


\section{Giriş}

Antibiyotikler hayvancılık sektöründe uzun yıllar yem katkı maddesi olarak kullanılmıştır. Amaç kısa sürede daha az riskle daha fazla ürün elde etmek ve doğal olarak karlılığı artırmaktı. Ancak antibiyotiklere karşı direnç geliştiren patojen mikroorganizmalar ve ürünlerde kalıntı varlığının anlaşılmasından sonra (Hinton, 1988; Newman, 2002), pek çok ülkede yem katkı maddesi olarak kullanımı yasaklanmıştır (Ceylan ve ark., 2003). Yine benzer amaçla kanatlı hayvanlar ve bunlardan elde edilen ürünlerde oluşan lipid oksidasyonu engellemek için butil hidroksitoluen (BHT), butil hidroksianisol (BHA), tersiyer butil hidroksikinon (TBHQ) ve propil gallatlar gibi sentetik veya vitamin $\mathrm{E}, \mathrm{C}$ ve $\beta$-karotenler gibi doğal antioksidan maddeler yem katkı maddesi olarak kullanılmıştır. Üreticiler ucuz olmaları, yüksek düzeyde stabilite ve güçlü antioksidan aktivite göstermelerinden dolayı sentetik antioksidanları tercih ederken (Bandoniene ve ark., 2002), tüketiciler sentetik katkıların insan sağlığını olumsuz yönde etkileyeceğinden endişe etmektedir. Son dönemlerde yapılan bazı toksikolojik çalışmalarla bu sentetik antioksidanların kanserli hücre gelişimini teşvik ettiği ve toksik etkilere sahip olduğu ortaya çıkmıştır (Botsoglou ve ark., 2002). Ayrıca sentetik antioksidanların kızartılmış ürünlerde tam etki göstermediği, hoş olmayan tat ve kokulara sebep olduğu ve en önemlisi kanserli hücre oluşumunu uyararak insan sağlığını olumsuz yönde etkilediği belirlenmiştir. $\mathrm{Bu}$ yüzden Avrupa Birliği ülkeleri ve bazı Asya ülkelerinde sentetik antioksidanların kullanımları ya kısıtlanmış ya da yasaklanmıştır (Akgül, 1989; Akgül ve Ayar, 1993). Doğal bir antioksidan olan vitamin E ile yapılan çalışmalarda, kesimden önceki 28 gün boyunca en az 200 $\mathrm{mg} / \mathrm{kg}$ vitamin E ilavesinin etlik piliçlerde lipid peroksidasyonunu engellediği ortaya konulmuştur (Marrissey ve ark., 1997). Vitamin E'nin hindi etlerinin saklanmasında oksidatif bozulmaya engel olduğunu (Govaris ve ark., 2007), 21 ve 42 gün depolanan yumurtalarda Tiyobarbitürik asid-reaktif maddeler (TBARS) oluşumunu önemli derecede yavaşlattığını belirtmişlerdir (Kaya ve Turgut, 2012). Ancak tokoferollerin kimyasallara göre dayanıksız olması kullanımında bazı güçlüklere neden olmaktadır (Akgül ve Ayar, 1993). İşte tüm bu nedenler hayvan beslemede farklı doğal ürünlerin arayış sürecini başlatmıştır. Bitkiler farklı bileşenlere sahip, kompleks karışımlar olup, sentezledikleri flavonoid, terpenoid alkaloid, kinin, berberin, tanin gibi maddeler pekçok hastalığın tedavisinde etkin biçimde kullanılmaktadır (Korukluoğlu ve ark., 2006). Bu konuda ilgi çeken bitkilerden biri de biberiyedir. Yapılan çalışmalarda biberiyenin antimikrobiyal, antioksidan ve bağ 1 şılklı sistemini iyileştirici etkileri olduğu (Gachkar ve ark., 2007), bitkiden elde edilen uçucu yağın antimikrobiyal (Elgayyar ve ark., 2001; Gachkar ve ark., 2007), ekstraktın ise antioksidan (Bracco ve ark., 1981) etkisinin güçlü olduğu bildirilmiştir. Yine farklı bir çalışmada biberiye bitki ekstraktın da bulunan karnosik asitin BHT (butil hidroksitoluen) ve BHA'den (butil hidroksianisol) yedi kat daha fazla antioksidan etkiye sahip olduğu belirtilmiştir (Richheimer ve ark., 1996). Ancak hayvan beslemede bitkisel ekstraktlardan yararlanma oldukça sınırlıdır. Bitkisel ekstraktların etkilerinin tam anlamıyla belirlenmesi için daha fazla bilimsel çalışmaya ihtiyaç duyulmaktadır. Bu kapsamda çalışma Türkiye'de yaygın olarak bulunan ve üretimi yapılan biberiye uçucu yağının yumurtac tavuk yemlerine ilave edilmesinin performans, yumurta kalite kriterleri ve depolamanın yumurta sarıs1 malondialdehit (MDA) düzeyi üzerindeki etkilerini vitamin $\mathrm{E}$ ve antibiyotikle beslenen gruplar ile karşılaştırmalı olarak belirlemek ve alternatif bir yem katk1 maddesi olarak yumurtac1 tavuk yemlerinde kullanım olanağını değerlendirebilmek amacıyla yapilmıştır.

\section{Materyal ve Metot}

Bu çalışma Yüzüncü Yıl Üniversitesi Bilimsel Araştırma Projeleri Başkanlığı tarafından 2011-FBE D029 No'lu proje olarak desteklenmiş ve Yüzüncü Y1l Üniversitesi Hayvan Deneyleri Yerel Etik Kurulu'nun 02/01/2014 ve 2014/01 say1l kararı ile kabul edilmiştir. Araştırma alanı Etaş Afyon Tavukçuluk İşletmesi tarafından sağlanmıştır. Hayvan materyalini 240 adet 32 haftalık yaşta Bovans genotipi beyaz yumurtacı tavuklar oluşturmuştur. Yem materyali olarak birinci dönem kafes yumurta tavuğu yemi kullanılmış, yem ve su ad-libitum olarak verilmiştir. Yemlerin ham besin madde içeriği AOAC (1984)'e bildirilen yöntemlere göre belirlenmiş ve Tablo 1'de verilmiştir.

Karma yemler izonitrojenik ve izokalorik olacak şekilde hazırlanmıştır. Biberiye uçucu yağı, denemede kullanılan bitkisel yağa farklı düzeylerde karıştırılmış ve daha sonra bu yağ karışımı yeme ilave edilmiştir (Şimşek ve ark., 2005). Yemin Metabolik Enerji düzeyi Carpenter ve Clegs (1956)'e göre hesaplanmıştır.

Antibiyotik [(Klortetrasiklin) Vimar G1da Tarım Hayvancılık Anonim Şirketi)], vitamin E [(DL- $\alpha-$ tokoferol asetat) (Ekol Gida Tarım Hayvancılık Pazarlama Sanayi ve Ticaret Anonim Şirketi)] ve biberiye [(Rosmarinus officinalis L.) (Agromiks Yem Katk1 Maddeleri Hayvancılık Gıda San. ve Tic. Ltd. Şti. Güzelbahçe- IZMİR] ticari bir firmadan temin edilmiş olup, biberiye uçucu yağı Ege Üniversitesi İlaç Geliştirme ve Farmakokinetik Araştırma ve Uygulama Merkezi Çevre ve Gida Analizleri laboratuvarlarında Pharmacopeia National Formularty USP 23 NF 18, p 1755 (1995) analiz yöntemine göre yapılmıştır (Tablo 2).

Kümeste 16 saat aydınlık 8 saat karanlık aydınlatma programı uygulanmıştır. Optimum sıcaklık $21-23^{\circ} \mathrm{C}$ arasında tutulmuştur. Çalışma, tesadüf parselleri deneme deseninde 3 ay (90 gün) sürdürülmüştür. Deneme grupları Tablo 3 deki gibi oluşturulmuştur.

Çalışmanın başında ve sonunda grupların canlı ağırlıkları belirlenmiş ve canlı ağırlı değişimleri hesaplanmıştır. Yem tüketimleri 15 günde bir tüketilen toplam yem miktarının gün ve hayvan sayısına bölünmesiyle belirlenmiştir. 15 günde bir toplam tüketilen yemin $(\mathrm{kg})$, üretilen yumurta miktarına $(\mathrm{kg})$ bölünmesiyle yemden yararlanma oranları belirlenmiştir. Her gün aynı saatte (14:00 - 15:00) toplanan yumurtalar kaydedilerek yumurta verimleri ve hasarlı yumurta oranları tespit edilmiştir. Yumurtalar 24 saat oda sıcaklığında 
bekletildikten sonra tartılarak yumurta ağırlıkları belirlenmiştir. Yumurta kalite kriterleri ayda bir 90 adet yumurtada (her bir tekerrürden rastgele seçilen 3 adet olmak üzere 1 grup için 15 adet, 6 grup için 90 adet), 3 ayda toplamda 270 adet yumurtada belirlenmiştir. Ölümler günlük olarak kaydedilmiştir. Yumurta sarı ve ak yüksekliği $0,01 \mathrm{~mm}$ 'ye hassas üçayaklı mikrometre ile sarı çapı, ak uzunluğu ve genişliği ise $0,01 \mathrm{~mm}$ 'ye hassas dijital sürgülü kumpas ile ölçülerek kaydedilmiş ve şekil indeksi, sarı indeksi, ak indeksi ve haugh birimi (Haugh, 1937) aşağıdaki şekilde hesaplanmış, yumurta sarı rengi ise Roche renk skalası ile tespit edilmiştir.

$$
\begin{aligned}
& \text { Şekil indeksi (\%) }=\frac{Y E}{Y B} \times 100 \\
& \text { Sarı indeksi }(\%)=\frac{S Y}{S G} \times 100
\end{aligned}
$$

$$
\operatorname{Ak} \text { indeksi }(\%)=\left[\frac{\mathrm{AY}}{(\mathrm{AU}+\mathrm{AG}) / 2}\right] \times 100
$$

Haugh birimi $=100 \times \log \left(\mathrm{AY}+7,57-1,7 \times \mathrm{YA}^{0,37}\right)$

$$
\begin{aligned}
\text { YE } & =\text { Yumurtanın eni } \\
\text { YB } & =\text { Yumurtanın boyu } \\
\text { SY } & =\text { Sarı yüksekliği } \\
\text { SG } & =\text { Sarı genişliği } \\
\text { AY } & =\text { Ak yüksekliği } \\
\text { AU } & =\text { Ak uzunluğu } \\
\text { AG } & =\text { Ak genişliği } \\
\text { YA } & =\text { Yumurta Ağırlığ }
\end{aligned}
$$

Yumurta sarısında MDA düzeyi ölçümü: Her bir tekerrürden 4'er adet olmak üzere 120 adet yumurta her bir depolama süresi için ayrılmış (1., 14., 28., 42. ve 56. gün) ve oda sicaklığında $\left(16 \pm 2^{\circ} \mathrm{C}\right)$ depolanmıştır. Yumurtalar Ahi Evran Üniversitesi Biyokimya Laboratuvar'ında analiz edilmiștir. Yumurta sarısının içerdiği protein miktarı Layne (1957)'nın Biüret Protein analizi metoduna göre belirlenmiştir. Yumurta sarıs1 MDA analizi Buege ve Aust (1978)'e göre yapılmış ve yumurta sarısının tiyobarbitürik asit reaktif maddeler (TBARS) değeri malondialdehit olarak aşağıdaki şekilde hesaplanmıştır.

$$
\text { Malondialdehit }=\frac{\mathrm{OD} \times \mathrm{OH}}{1,56 \times 10^{5} \times \mathrm{TH} \times \mathrm{P}}
$$

$\mathrm{OD}=$ Absorbans değeri

\begin{tabular}{|c|c|}
\hline Hammadde & $\mathrm{kg} / \mathrm{ton}$ \\
\hline Misir & 632,75 \\
\hline Soya Fasulyesi Küspesi & 160,75 \\
\hline ATK & 45 \\
\hline Tam Yağlı Soya (Fulfat Soya) & 29 \\
\hline Mermer Tozu & 82 \\
\hline Et kemik unu & 25 \\
\hline Vitamin Mineral Karışımı & 25 \\
\hline Bitkisel yağ (Ayçiçeği Yağı) & 0,5 \\
\hline Toplam & 1000 \\
\hline Analizle Bulunan Besin Madde İçeriği & $\%$ \\
\hline Kuru Madde & 90,83 \\
\hline Ham Protein & 16,27 \\
\hline Ham Yağ & 3,66 \\
\hline Ham Selüloz & 3,46 \\
\hline Ham Kül & 9,39 \\
\hline Nişasta & 41,0 \\
\hline Şeker & 3,6 \\
\hline Metobolik Enerji (Kcal/Kg) & 2841,63 \\
\hline Hesaplanan Besin Madde İçeriği & $\%$ \\
\hline Lizin & 0,83 \\
\hline Metiyonin & 0,42 \\
\hline Metiyonin+Sistin & 0,72 \\
\hline Linoleik Asit & 1,21 \\
\hline Kalsiyum & 3,83 \\
\hline Yararlanılabilir Fosfor & 0,40 \\
\hline Sodyum & 0,20 \\
\hline Klor & 0,18 \\
\hline
\end{tabular}

ÖH $=$ Örnek hacmi

$\mathrm{TH}=$ Toplam hacim

$\mathrm{P} \quad=$ Protein $(\mathrm{mg} / \mathrm{ml})$

Araştırmada elde edilen veriler; MINITAB $14.1 \mathrm{~V}$ paket programı yardımıyla General Linear Model prosedürü ile varyans analizine tabi tutulmuştur. Gruplara ait ortalamalar arasındaki farklılıkların önemli olup olmadıklarının belirlenmesi için çoklu karşılaştırma testlerinden Duncan testi kullanılmıştır (Düzgüneş ve ark., 1987).

Tablo 1 Birinci dönem kafes yumurtacı tavuk yeminin bileşimi ve besin madde kompozisyonu

1 kg premix içeriğinde: 3.600mg Glucan, 2.400mg Manan, 75.000 HUT Proteaz, 500 CMCU Selülaz, $240 \mathrm{mg}$ Çinko, $40 \mathrm{mg}$ Bakır, $180 \mathrm{mg}$ Mangan, 1.800 SPU 3 Phytase, $47.520 \mathrm{mg}$ DL- Methionin, $32.400 \mathrm{mg}$ Fosfor, $480.000 \mathrm{IU}$ Vitamin A, $100.000 \mathrm{IU}$ Vitamin D3, 1,200 mg Vitamin E, $160 \mathrm{mg}$ Vitamin K3, $120 \mathrm{mg}$ Vitamin B1, $280 \mathrm{mg}$ Vitamin B2, $1.200 \mathrm{mg}$ Niacin, $200 \mathrm{mg}$ Vitamin B6, $0.6 \mathrm{mg}$ Vitamin B12, 2. $000 \mathrm{mg}$ Vitamin C, $400 \mathrm{mg}$ Ca-D-Pantothenate, 1.8mg D-Biotin, $40 \mathrm{mg}$ Folik Asit, $8.000 \mathrm{mg}$ Kolin Klorür, $140 \mathrm{mg}$ Cantaxanthin, $40 \mathrm{mg}$ İyot, $6 \mathrm{mg}$ Selenyum ve $200.000 \mathrm{mg}$ NuPro. 
Tablo 2 Biberiye uçucu yağının kimyasal bileşimi ve etken madde oranları (\%)

\begin{tabular}{l|clc}
\hline \multicolumn{1}{c|}{ Aktif madde } & $\%$ & \multicolumn{1}{c}{ Aktif madde } & $\%$ \\
\hline 1.8 Cineole & 45,04 & Alpha humulene & 1,23 \\
Alpha Pinen & 13,30 & Caryophyllene oxide & 0,56 \\
Trans Caryophyllene & 7,57 & Beta Bisabolene & 0,35 \\
(+) Campher & 5,51 & $1-$-Octen-3-Ol & 0,29 \\
(+)Borneol & 4,44 & Delta Cadinen & 0,29 \\
Para Cymen & 3,71 & Alpha copaene & 0,28 \\
Camphene & 3,56 & Alpha Terpinen & 0,25 \\
Alpha Terpineol & 3,35 & Delta 3 Caren & 0,18 \\
Limonen & 2,80 & Gamma Terpinen & 0,25 \\
Beta Myrcene & 2,24 & Alpha Fenchene & 0,17 \\
Levo-bornyl acetate & 1,93 & Tricylene & 0,14 \\
\hline
\end{tabular}

Tablo 3 Deneme gruplarının oluşturulması

\begin{tabular}{l|ll}
\hline Grupları & Muameleler & Yem katkıları \\
\hline 1.Grup & NK & SBKY (özel katk1 maddesi içermeyen birinci dönem yumurtacı kafes tavuk yemi) \\
2.Grup & PK1 & SBKY $+500 \mathrm{mg} / \mathrm{kg}$ düzeyinde antibiyotik (Klortetrasiklin) katkılı karma yem \\
3.Grup & PK2 & SBKY $+200 \mathrm{mg} / \mathrm{kg}$ düzeyinde vitamin E katk1lı karma yem \\
4.Grup & B1 & SBKY $+100 \mathrm{mg} / \mathrm{kg}$ düzeyinde biberiye uçucu yağ katk1lı karma yem \\
5.Grup & B2 & SBKY $+200 \mathrm{mg} / \mathrm{kg}$ düzeyinde biberiye uçucu yağ katkılı karma yem \\
6.Grup & B3 & SBKY $+300 \mathrm{mg} / \mathrm{kg}$ düzeyinde biberiye uçucu yağ1 katkılı karma yem \\
\hline
\end{tabular}

NK: Negatif Kontrol, SBKY: Standart Bazal Karma Yem, PK1: Pozitif Kontrol 1(Antibiyotik), PK2: Pozitif Kontrol 2(Vitamin E), B1: Biberiye100 $\mathrm{mg} / \mathrm{kg}$, B2: Biberiye $200 \mathrm{mg} / \mathrm{kg}$, B3: Biberiye $300 \mathrm{mg} / \mathrm{kg}$

\section{Bulgular ve Tartışma}

Yumurtacı tavukların deneme başı, deneme sonu canlı ağırlıkları, canlı ağırlık artışı, yumurta üretimi, yumurta ağırlığı, hasarlı yumurta oranı ve ölüm oranları bakımından grup ortalamaları arasındaki farklılıklar önemsiz bulunmuştur $(\mathrm{P}>0,05)$ (Tablo 4). Bu sonuçlar yemlere biberiye uçucu yağı ilavesinin canlı ağırlık (Yeşilbağ ve ark., 2013; Çiftçi ve ark., 2013), yumurta verimi ve yumurta ağırlığı (Orhan ve Eren, 2011) üzerine önemli bir etkisinin olmadığını bildiren çalışmalarla benzerlik göstermektedir. Tablo 4'de görüldügüu gibi negatif kontrol grubuna göre yeme ilave edilen tüm katkılar yem tüketimini düşürmüş, 200 ve 300 mg/kg biberiye uçucu yağı ve vitamin E ilavesi diğer gruplara göre yemden yararlanma oranını önemli düzeyde artırmıştır $(\mathrm{P}<0,05)$. Benzer şekilde biberiye yağı içeren deneme gruplarında yem tüketiminin düştüğü ve yemden yararlanmanın önemli oranda arttığını saptamışlardır (Buğdaycı ve Ergün, 2011; Yeşilbağ ve ark., 2013). Yem tüketimindeki azalma ve yemden yararlanmada ki iyileşme kullanılan katkılarının doğrudan sindirim sistemini üzerindeki olumlu etkilerinden olabilir. Iqbal ve ark., (2013) vitamin E'nin yumurtacı tavukların hastalıklara karşı direncini artırarak bağışıklık sistemini güçlendirici etki gösterdiğini, yem değerlendirme oranı, yumurta üretimi ve karaciğer fonksiyonları üzerinde olumlu bir etkiye sahip olduğunu belirlemişlerdir. Yine antibiyotik (Hernandez ve ark., 2004; Mathlouthi ve ark., 2012) ve vitamin E'nin sindirim sistemi üzerine olan olumlu etkilerinden söz edilmektedir (Iqbal ve ark., 2013). Tablo 2'de verilen analiz sonuçlarına göre biberiye \%45,04 oranında 1,8 Cineole bileşiği içermektedir. Bazı araştırma bulguları bu fenolik bileşiği sindirim sistemi üzerinde antioksidan ve antimikrobiyal özelliğe sahip olduğu, sindirim sistemi, dolayısıyla da hayvan sağlı̆̆ını ve bağışıklık sistemini olumlu yönde etkilediği (Gachkar ve ark., 2007), sindirim enzimlerinin aktivitesini yükselterek sindirimi artırdığı yönündedir (Jamroz ve Kamel, 2002). Aynı şekilde biberiye bitkisinin öğütülmüş veya uçucu yağ olarak yeme ilavesinin bazı performans değerlerini olumlu etkilediği belirlenmiştir (Botsoglou ve ark.,; 2005; Mitsopoulos ve ark., 2006; Beyazıtoğlu, 2009). Aynı bitkiyle benzer şekilde çalışılmasına rağmen farklı sonuçlar alınmasının nedenleri arasında; yapılarındaki etken maddelerin çeşidi, kimyasal yapısı, miktarları, bitkinin yetiştiği bölge, hasat zamanı, kullanılan bitki kısmı, fenolik yap1 ve konsantrasyonu, ekstraksiyon yöntemi, ürün ve oksidasyon koşulları ve hayvan türü gibi faktörlerin (Malayoğlu, 2010) yanında çeşitli sebeplerle oluşan stresin kanatlilarda çeşitli doku ve sistemleri etkilediği, bu etkileri azaltmada ise aydınlatma programları ve vitamin uygulamalarının yanında, bitki ekstraktları üzerinde durulduğu (Taşkın ve ark., 2015) antioksidan özelliğe sahip bu tür bitki ekstraktları (Çabuk ve ark., 2006) ve vitamin E'nin olumlu etkilerinin stres faktörlerinin varlığında daha belirgin hale gelebildiği ifade edilmektedir (Şahin ve ark., 2002).

Muamele grupları arasında yumurta kabuk ağırlığı, kabuk kalınlığı, kabuk kırılma mukavemeti, şekil indeksi, sarı indeksi, ak indeksi, Haugh Birimi ve sarı renk değerleri bakımından istatistikî bir farklılık görülmemiştir (Tablo 5). Bu sonuçların yapılan bazı çalışmalar ile uyumlu olduğu gözlenirken (Florou-Paneri ve ark., 2006; Yeşilbağ ve ark., 2013), mannan-oligosakkarit ve uçucu yağ karışımı ile beslemenin yumurta kabuk ağırlığını artırmakla birlikte diğer yumurta kalite kriterlerini etkilemediğini bildiren çalışma sonuçları ile kısmi bir uyum göstermektedir (Bozkurt ve ark., 2012). Diğer taraftan sarı ve ak indeksi değerlerini önemli oranda arttırdığı, sarı rengini önemli ölçüde koyulaştırdığı bildiren bulgular ile de çelişki oluşturmaktadır (Yeşilbağ ve ark., 2013) 
Tablo 4 Muamele gruplarının performans değerleri

\begin{tabular}{l|ccccccc}
\hline \multirow{2}{*}{ Parametreler } & \multicolumn{7}{c}{ Gruplar } \\
\cline { 2 - 8 } & Kegatif & $\begin{array}{c}\text { Antibiyotik } \\
(500 \mathrm{mg} / \mathrm{kg})\end{array}$ & $\begin{array}{c}\text { Vitamin E } \\
(200 \mathrm{mg} / \mathrm{kg})\end{array}$ & $\begin{array}{c}\text { Biberiye } \\
(100 \mathrm{mg} / \mathrm{kg})\end{array}$ & $\begin{array}{c}\text { Biberiye } \\
(200 \mathrm{mg} / \mathrm{kg})\end{array}$ & $\begin{array}{c}\text { Biberiye } \\
(300 \mathrm{mg} / \mathrm{kg}\end{array}$ & $\mathrm{P}$ \\
\hline BCA & $1620,6 \pm 11,7$ & $1618,6 \pm 27,9$ & $1611,4 \pm 13,8$ & $1622,1 \pm 13,1$ & $1629,1 \pm 12,4$ & $1631,9 \pm 17,1$ & 0,465 \\
FCA & $1750,4 \pm 15,0$ & $1751,2 \pm 22,7$ & $1742,5 \pm 18,8$ & $1759,4 \pm 24,0$ & $1775,8 \pm 18,9$ & $1737,0 \pm 44,4$ & 0,258 \\
CAA & $129,77 \pm 16,99$ & $132,65 \pm 45,68$ & $131,06 \pm 26,08$ & $137,30 \pm 22,50$ & $146,72 \pm 27,29$ & $105,10 \pm 30,90$ & 0,389 \\
YT & $117,76 \pm 2,45^{\mathrm{a}}$ & $115,74 \pm 0,52^{\mathrm{b}}$ & $114,88 \pm 0,71^{\mathrm{b}}$ & $114,22 \pm 2,74^{\mathrm{b}}$ & $115,55 \pm 0,86^{\mathrm{b}}$ & $114,29 \pm 0,64^{\mathrm{b}}$ & 0,020 \\
YYO & $1,93 \pm 0,04^{\mathrm{a}}$ & $1,96 \pm 0,10^{\mathrm{a}}$ & $1,88 \pm 0,04^{\mathrm{b}}$ & $1,97 \pm 0,07^{\mathrm{a}}$ & $1,87 \pm 0,01^{\mathrm{b}}$ & $1,85 \pm 0,05^{\mathrm{b}}$ & 0,028 \\
YV & $96,34 \pm 2,09$ & $95,63 \pm 4,25$ & $98,10 \pm 0,92$ & $94,41 \pm 5,24$ & $97,55 \pm 1,16$ & $97,11 \pm 2,84$ & 0,486 \\
YA & $63,33 \pm 1,25$ & $62,15 \pm 1,24$ & $62,10 \pm 1,06$ & $61,88 \pm 0,84$ & $63,47 \pm 0,57$ & $63,55 \pm 1,30$ & 0,050 \\
HYO & $0,68 \pm 0,98$ & $0,46 \pm 0,61$ & $0,15 \pm 0,15$ & $0,36 \pm 0,23$ & $0,47 \pm 0,46$ & $0,15 \pm 0,15$ & 0,572 \\
ÖO & & 2,5 & & 2,5 & 2,5 & & \\
\hline
\end{tabular}

a,b: Aynı satırdaki farklı harfleri taşıyan ortalamalar arasındaki fark önemlidir ( $\mathrm{P}<0,05)$; BCA: Başlangıç canlı ağılılk (g), FCA: Final canlı ağırlık (g), CAA: Canlı ağırlık artışı (g), YT: Yem tüketimi (g/gün), YYO: Yemden yararlanma oranı (kg yem/kg yumurta), YV: Yumurta verimi (\%), YA: Yumurta ağırlığı (g), HYO: Hasarlı yumurta oranı (\%), ÖO: ölüm oranı (\%)

Tablo 5 Muamele gruplarının yumurta kalite kriterleri değerleri

\begin{tabular}{|c|c|c|c|c|c|c|c|}
\hline \multirow[b]{2}{*}{ Parametreler } & \multicolumn{7}{|c|}{ Gruplar } \\
\hline & $\begin{array}{l}\text { Negatif } \\
\text { Kontrol }\end{array}$ & $\begin{array}{l}\text { Antibiyotik } \\
(500 \mathrm{mg} / \mathrm{kg})\end{array}$ & $\begin{array}{c}\text { Vitamin E } \\
(200 \mathrm{mg} / \mathrm{kg})\end{array}$ & $\begin{array}{c}\text { Biberiye } \\
(100 \mathrm{mg} / \mathrm{kg})\end{array}$ & $\begin{array}{c}\text { Biberiye } \\
(200 \mathrm{mg} / \mathrm{kg})\end{array}$ & $\begin{array}{c}\text { Biberiye } \\
(300 \mathrm{mg} / \mathrm{kg}\end{array}$ & $\mathrm{P}$ \\
\hline KA & $7,74 \pm 0,16$ & $7,39 \pm 0,14$ & $7,51 \pm 0,26$ & $7,35 \pm 0,36$ & $7,49 \pm 0,15$ & $7,52 \pm 0,27$ & 0,205 \\
\hline KK & $0,44 \pm 0,01$ & $0,43 \pm 0,01$ & $0,43 \pm 0,01$ & $0,43 \pm 0,01$ & $0,43 \pm 0,01$ & $0,43 \pm 0,01$ & 0,328 \\
\hline KKD & $3,36 \pm 0,39$ & $3,46 \pm 0,23$ & $3,59 \pm 0,34$ & $3,73 \pm 0,44$ & $3,69 \pm 0,25$ & $3,69 \pm 0,24$ & 0,413 \\
\hline Şİ & $76,93 \pm 0,53$ & $77,75 \pm 0,41$ & $77,49 \pm 0,74$ & $77,67 \pm 0,95$ & $77,53 \pm 0,47$ & $77,27 \pm 0,97$ & 0,516 \\
\hline Sİ & $41,53 \pm 0,90$ & $41,79 \pm 1,10$ & $42,28 \pm 0,70$ & $41,66 \pm 0,85$ & $42,23 \pm 0,88$ & $41,43 \pm 0,33$ & 0,470 \\
\hline $\mathrm{AI}$ & $8,86 \pm 0,18$ & $8,68 \pm 0,27$ & $8,95 \pm 0,24$ & $9,05 \pm 0,27$ & $9,04 \pm 0,16$ & $8,84 \pm 0,29$ & 0,190 \\
\hline $\mathrm{HB}$ & $82,82 \pm 1,20$ & $83,78 \pm 1,19$ & $84,73 \pm 1,42$ & $84,64 \pm 0,92$ & $84,53 \pm 1,09$ & $84,71 \pm 1,23$ & 0,104 \\
\hline SR & $11,42 \pm 0,34$ & $11,55 \pm 0,14$ & $11,51 \pm 0,10$ & $11,78 \pm 0,15$ & $11,68 \pm 0,35$ & $11,71 \pm 0,20$ & 0,177 \\
\hline
\end{tabular}

KA: Kabuk ağırlığı (g), KK: Kabuk kalınlığı (mm), KKD: Kabuk kırılma direnci (kg/ $\left.\mathrm{cm}^{2}\right)$, Șİ: Șekil indeksi (\%), Sİ: Sarı indeksi (\%), Aİ: Ak indeksi (\%), HB: Haugh Birimi, SR: Sarı Rengi

Tablo 6 Muamele grupları ve depolama süresine göre yumurta sarısı MDA düzeyleri (MDA, nmol/mg)

\begin{tabular}{|c|c|c|c|c|c|c|c|}
\hline \multirow{2}{*}{$\begin{array}{l}\text { Depolama } \\
\text { periyotları }\end{array}$} & \multicolumn{7}{|c|}{ Gruplar } \\
\hline & $\begin{array}{l}\text { Negatif } \\
\text { Kontrol }\end{array}$ & $\begin{array}{l}\text { Antibiyotik } \\
(500 \mathrm{mg} / \mathrm{kg})\end{array}$ & $\begin{array}{c}\text { Vitamin E } \\
(200 \mathrm{mg} / \mathrm{kg})\end{array}$ & $\begin{array}{c}\text { Biberiye } \\
(100 \mathrm{mg} / \mathrm{kg})\end{array}$ & $\begin{array}{c}\text { Biberiye } \\
(200 \mathrm{mg} / \mathrm{kg})\end{array}$ & $\begin{array}{c}\text { Biberiye } \\
(300 \mathrm{mg} / \mathrm{kg}\end{array}$ & $P$ \\
\hline 1. Gün & $0,122 \pm 0,03 \mathrm{a}^{\mathrm{C}}$ & $0,096 \pm 0,02 a b^{C}$ & $0,070 \pm 0,00 b^{c}$ & $0,107 \pm 0,02 a^{c}$ & $0,114 \pm 0,03 \mathrm{a}^{\mathrm{C}}$ & $0,109 \pm 0,02 \mathrm{a}^{\mathrm{C}}$ & 0,015 \\
\hline 14. Gün & $0,120 \pm 0,02 \mathrm{a}^{\mathrm{C}}$ & $0,115 \pm 0,02 \mathrm{a}^{\mathrm{C}}$ & $0,073 \pm 0,03 b^{C}$ & $0,110 \pm 0,01 \mathrm{a}^{\mathrm{C}}$ & $0,118 \pm 0,04 \mathrm{a}^{\mathrm{C}}$ & $0,121 \pm 0,01 \mathrm{a}^{\mathrm{C}}$ & 0,040 \\
\hline 28. Gün & $0,127 \pm 0,03 \mathrm{a}^{\mathrm{C}}$ & $0,132 \pm 0,02 \mathrm{a}^{\mathrm{B}}$ & $0,071 \pm 0,02 b^{C}$ & $0,120 \pm 0,01 \mathrm{a}^{\mathrm{B}}$ & $0,138 \pm 0,04 \mathrm{a}^{\mathrm{B}}$ & $0,135 \pm 0,01 \mathrm{a}^{\mathrm{B}}$ & 0,001 \\
\hline 42. Gün & $0,163 \pm 0,04 a^{B}$ & $0,138 \pm 0,04 b^{B}$ & $0,107 \pm 0,01 c^{\mathrm{B}}$ & $0,132 \pm 0,02 b^{\mathrm{B}}$ & $0,166 \pm 0,02 \mathrm{a}^{\mathrm{B}}$ & $0,150 \pm 0,03 \mathrm{a}^{\mathrm{B}}$ & 0,031 \\
\hline 56. Gün & $0,231 \pm 0,02 \mathrm{a}^{\mathrm{A}}$ & $0,167 \pm 0,03 b^{\mathrm{A}}$ & $0,135 \pm 0,02 c^{\mathrm{A}}$ & $0,177 \pm 0,04 b^{\mathrm{A}}$ & $0,208 \pm 0,05 \mathrm{a}^{\mathrm{A}}$ & $0,217 \pm 0,02 \mathrm{a}^{\mathrm{A}}$ & 0,001 \\
\hline 1-56. Gün & $0,153 \pm 0,01 \mathrm{a}^{\mathrm{B}}$ & $0,130 \pm 0,02 b^{\mathrm{B}}$ & $0,092 \pm 0,01 \mathrm{c}^{\mathrm{BC}}$ & $0,129 \pm 0,01 b^{\mathrm{B}}$ & $0,149 \pm 0,01 \mathrm{a}^{\mathrm{B}}$ & $0,147 \pm 0,01 \mathrm{a}^{\mathrm{B}}$ & 0,000 \\
\hline $\mathrm{P}$ & 0,000 & 0,010 & 0,000 & 0,000 & 0,001 & 0,000 & \\
\hline
\end{tabular}

a,b,c: Aynı satırda farklı harfleri tașıyan ortalamalar arasındaki fark önemlidir $(\mathrm{P}<0,05)$

A,B,C: Aynı sütunda farklı harfleri taşıyan ortalamalar arasındaki fark önemlidir $(\mathrm{P}<0,05)$

Yumurta sarısında oluşan lipid peroksidasyon parametresi olarak bilinen MDA değerleri bakımından, gruplar aras1 farkl1l1k depolamanın 1., 14. ve 42. günlerinde önemli iken $(\mathrm{P}<0,05), 28$., 56. ve 1-56. günlerde ise çok önemli $(\mathrm{P}<0,01)$ bulunmuştur (Tablo 6).

Muamele gruplarının kendi içerisinde zamana bağlı olarak değişiminde negatif kontrol, antibiyotik, vitamin E ve biberiye uçucu yağının her üç dozununda MDA değerlerinde oluşan fark önemli bulunmuştur $(P<0,01)$ (Tablo 6).

Yumurta sarısı malondialdehit (MDA) değerlerine bakıldı̆̆ında, yeme $200 \mathrm{mg} / \mathrm{kg}$ vitamin $\mathrm{E}$ ilavesi depolamanın 1. günü negatif kontrol ve tüm biberiye uçucu yağ ilaveli gruplarına göre, $14,28,42,56$. ve 1-56. günlerinde ise tüm yemleme gruplarına göre önemli düzeyde düşürmüştür $(\mathrm{P}<0,05)$ (Tablo 6). Çalışmadan elde edilen bulgular, lipid oksidasyonu engelleme açısından $\alpha$-tokoferol asetatın bitki ektraktlarına göre daha etkili olduğunu bildiren bulgularla tam bir benzerlik gösterirken (Lopez-Bote ve ark., 1998; Botsoglou ve ark., 2013), biberiye, kekik ve zerdaçal gibi uçucu yağların yumurta sarısı MDA düzeylerini önemli oranda düşürdüğünü bildiren çalışmalar ile kısmen benzerlik göstermektedir (Yeşilbağ ve ark., 2013; Radwan Nadia ve ark., 2008). Diğer taraftan biberiyenin antioksidan aktivitesinin doza bağlı olarak değiştiği ve doz arttıkça etkisinin arttığını belirten farklı çalışmalar da saptanmıștır (Florou-Paneri ve ark., 2006). Biberiyenin $100 \mathrm{mg} / \mathrm{kg}$ dozunun 200 ve $300 \mathrm{mg} / \mathrm{kg}$ dozuna göre yumurta sarıs1 MDA değerlerini önemli olarak düşürmesi ve artan dozların antioksidan etki göstermemesinin nedeni belki de Rietjens ve ark. (2002)'ın C vitamini, E vitamini, karotenoidler ve flavonoidler gibi doğal antioksidanların yüksek dozlarda tam tersi bir etki göstererek oksidasyonu 
hızlandırıcı bir etkiye sahip olabileceği şeklindeki görüşleri ile açıklanabilir. Yine etken maddesi klortetrasiklin olan yemle beslenen grubun yumurta sarıs1 MDA değerleri, negatif kontrol ve yüksek dozlarda biberiye uçucu yağı içeren gruplara göre önemli düzeyde düşük bulunmuştur $(\mathrm{P}<0,05)$. Bu durum, Kladna ve ark. (2012)'ın kesin olarak mekanizması bilinmemekle birlikte tetrasiklin grubu antibiyotiklerin antiradikal aktivite gösterdiği, hatta doğrudan serbest radikal süpürücü aktiviteye sahip olabileceğini bildiren ifadesi ile açıklanabilir.

Her grubun kendi içinde zamana bağlı olarak değişim sürecine bakıldığında, tüm muamele gruplarında 14. güne kadar değerlerde artış olmadığ 1 görülmektedir. 14. günden sonra antibiyotik ve biberiye uçucu yağ ilaveli yem gruplarında, 28. günden sonra ise negatif kontrol ve vitamin E ilaveli yem gruplarında değerlerin arttığ saptanmıştır $(\mathrm{P}<0,05) \quad$ (Tablo 6). Yumurtacı tavuk yemlerine bitkisel ekstrakt ve vitamin E ilavesinin 21. ve 42. gün depolanan yumurtalarda TBARS oluşumunu önemli derecede yavaşlattığı bildirilmektedir (Kaya ve Turgut, 2012). Tüm deneme gruplarına ait yumurta sarılarında ölçülen MDA değerleri zamana bağlı olarak artmış ve 56. günde 1. gün belirlenen değerlere göre yaklaşık iki katına ulaşmıştır. Bu durum her ne kadar antioksidan katkılar içeren yemlerle besleme sonucu elde edilen ürünler olsa da belli bir süre sonra zamana bağl1 istenmeyen değişimlerin olabildiğini göstermektedir. Ancak Tablo 6'da görüldüğü gibi 56 gün depolanan yumurtalarda $0,135(\mathrm{nmol} / \mathrm{mg})$ MDA değeri ile vitamin E grubu, diğer gruplardan önemli derecede düşüktür $(\mathrm{P}<0,001)$. Vitamin $\mathrm{E}$ ve biberiye ekstraktının MDA seviyelerini azaltarak oksidasyonuna karşı etkin rol oynadıkları (Florou-Paneri ve ark., 2006; Kaya ve Turgut, 2012), malondialdehit ve lipid hidroperoksit seviyelerinin azaldığ (Botsoglou ve ark., 2012) ve n-3- yağ asitleri ile zenginleştirilmiş yumurtalarda oksidatif stabilitenin arttığ bildirilmektedir (Botsoglou ve ark., 2013). Aynı araştırıcıların başka bir çalışmasında yumurta sarısı lipid oksidasyonunu engellemedeki siralamanın, $\alpha$-tokoferol asetat ve bitkisel ekstraktlar şeklinde olduğu, antioksidan özelliklerinin yemle yumurtaya taşınabildiği belirtilmiştir (Botsoglou ve ark., 2005). Çalışmanın sonucunda vitamin E'nin etkili bir antioksidan olduğu gözlemlenirken, biberiyenin antioksidan özelliğinin düşük bulunması belki de biberiyeden elde edilen uçucu yağ ve ekstraktın ana bileşenlerinin farklı olmasından ya da Del Baño ve ark. (2003)'ın belirttiği gibi biberiyenin antioksidan etkili bileşenleri, oranları ve aktivitelerinin mevsime, bölgelere, bitkinin kullanılan kısmına, elde ediliş yöntemi ve ekstraksiyonda kullanılan çözücüye göre değiştiği hatta genetik, su, 1ş1k ve vejetasyon döneminin farklı olmasından kaynaklanmış olabilir. Negatif kontrol grubuna göre tüm katkıların olumlu etki göstererek yem tüketimini düşürmesi, antibiyotik ve biberiyenin 100 $\mathrm{mg} / \mathrm{kg}$ dozu hariç diğer katkıların yemden yararlanma oranını iyileştirmesi ekonomik anlamda da olumlu sonuçlardır. Çalışmada yeme $200 \mathrm{mg} / \mathrm{kg}$ vitamin E katkısı, yumurta sarısı MDA analiz sonuçlarına göre lipid peroksidasyonunu düşürmüştür. Ancak 100 mg/kg biberiye uçucu yağının antioksidan özellik göstermesi, artan dozlarının oksidasyona karşı etkisiz veya hızlandırıcı etki göstermesi bu konuda daha ayrıntılı çalışmaların yapılması gerektiği sonucunu doğurmuştur. Ticari yetiştiricilikteki hayvan sağlığı ürün kalitesi, ürünlerin raf ömrü üzerine etkisi düşünüldüğünde, etkili bir antioksidan kaynağı olarak yeme ekstra $200 \mathrm{mg} / \mathrm{kg}$ vitamin E ve/veya $100 \mathrm{mg} / \mathrm{kg}$ biberiye uçucu yağ ilavesi lipid oksidasyonu önlemeye ve ürünün raf ömrünü artırmaya yönelik alternatif bir kaynak olarak yumurtacı karma yemlerinde kullanılabilir.

\section{Teşekkür}

$\mathrm{Bu}$ çalışma Yüzüncü Yıl Üniversitesi Bilimsel Araştırma Projeleri Başkanlığı tarafından 2011-FBE D029 No'lu proje olarak desteklenmiştir. Araştırma alanı Etaş Afyon Tavukçuluk İşletmesi tarafindan sağlanmıştır.

\section{Kaynaklar}

Akgül A. 1989. Baharatların antioksidan özellikleri. Doğa-TR J. of Agr. and Forestry, 13: 11-24.

Akgül A, Ayar A. 1993. Yerli baharatların antioksidan etkileri. Doğa-TR. J. of Agriculture and Forestry, 17: 1061-1068.

AOAC. 1984. Official Methods of Analysis (14th ed.), Association of Official Analytical Chemists, Washington, DC.

Bandoniene D, Venskutonis P R, Gruzdiene D, Murkovic M. 2002. Antioxidative activity of sage (Salvina officinalis L.) savory (Satureja hortensis L.) and borage (Borage officinalis L.) extracts in rapeseed oil. Eur. J. Lipid Sci. Technol, 104: 286-292.

Beyazıtoğlu Ş. 2009. Yüksek Sicaklık Altinda Rasyona Biyoantioksidan (Alfa-Tokoferol Asetat, Karvakrol, Karnosik Asit) Katkisinin Yumurtaci Tavuklarda Performans, Yumurta Verimi, Yumurta Kalitesi ve İmmun Sistem Uzerine Etkileri. Yüksek lisans tezi, Ç. Ü Fen Bilimleri Enstitüsü (Basılmamış), Adana.

Botsoglou NA, Florou-Paneri P, Christaki E, Fletouris DJ, Spais AB. 2002. Effect of dietary oregano essential oil on performance of chickens and on iron-induced lipid oxidation of breast, thigh and abdominal fat tissues. Br. Poult. Science, 43: 223-230.

Botsoglou N, Florou-Paneri P, Botsoglou E, Dotas V, Giannenas I, Koidis A, Mitrakos P. 2005. The effect of feeding rosemary, oregano, saffron and $\alpha$-tocopheryl acetate on hen performance and oxidative stability of eggs. South African Journal of Animal Science, 35: 143 - 151.

Botsoglou E, Govaris A, Fletouris D, Botsoglou N. 2012. Lipid oxidation of stored eggs enriched with very long chain n-3 fatty acids, as affected by dietary olive leaves (Olea europea L.) or a-tocopheryl acetate supplementation. Food Chemistry, 134: 1059-1068.

Botsoglou E, Govaris A, Fletouris D, Iliadis S. 2013. Olive leaves (Olea europea L.) and a-tocopheryl acetate as feed antioxidants for improving the oxidative stability of alinolenic acid-enriched eggs. Journal of Animal Physiology and Animal Nutrition 97: 740-753.

Bozkurt M, Küçükyılmaz K, Çatli AU, Çınar M, Bintas E, Coven F. 2012. Performance, egg quality, and immune response of laying hens fed diets supplemented with mannan-oligosaccharide or an essential oil mixture under moderate and hot environmental conditions. Poultry Science, 91: 1379-1386.

Bracco U, Loliger J, Viret JL. 1981. Production and use of natural antioxidants. Journal of the American Oil Chemists' Society, 58: 686-690.

Buege JA, Aust SD. 1978. Microsomal lipid peroxidation. Methods in Enzymology, 52: 302-310.

Buğdayc1 KE, Ergün A. 2011. Esansiyel yağ ve/veya probiyotiğin broylerlerde performans, immun sistem ve bazı kan parametreleri üzerine etkisi. Ankara Üniversitesi Veteriner Fakultesi Dergisi, 58: 279-284. 
Carpenter KJ, Clegg KM. 1956. The metabolizable energy of poultry feeding stuffs in relation to their chemical composition. J. Sci. Food Agriculture, 7: 45-51.

Ceylan N, Çiftçi İ, İlhan Z. 2003. Büyütme faktörü antibiyotiklere alternatif yem katkılarının etlik piliçlerde besi performansı ve bağırsak mikroflorası üzerine etkileri. Turk. J. Vet. Anim. Science, 27: 727-733.

Çabuk M, Bozkurt M, Alcicek A, Çatlı AU, Baser KHC. 2006. Effect of dietary essential oil mixture on performance of laying hens in the summer season. South Afr. J. Anim. Science 36: 215-221.

Çiftçi M, Şimşek ÜG, Azman MA, Çerçi İH, Tonbak F. 2013. The effects of dietary rosemary (Rosmarinus officinalis L.) oil supplementation on performance, carcass traits and some blood parameters of japanese quail under heat stressed condition. Kafkas Uni. Vet. Fakültesi Dergisi, 19(4): 595599.

Del Baño MJ, Lorente J, Castillo J, Benavente García O, Del Río JA, Ortuño A, Quirin KW, Gerard D. 2003. Phenolic diterpenes, flavones, and rosmarinic acid distribution during the development of leaves, flowers, stems, and roots of Rosmarinus officinalis Antioxidant activity. J. Agric. Food Chem., 51: 4247- 4253.

Düzgüneş O, Kesici T, Kavuncu O, Gürbüz F. 1987. Araştırma ve Deneme Metodları (İstatistik metodlar1-II). Ankara Üniversitesi Ziraat Fakültesi Yayınlar1:1021, Ders Kitab1 295s, Ankara.

Elgayyar M, Draughon FA, Golden DA, Mount JR. 2001. Antimicrobial activity of essential oils from plants against selected pathogenic and saprophytic microorganisms. J. Food Protection, 64: 1019- 1024.

Florou-Paneri P, Dotas D, Mitsopoulos I, Dotas V, Botsoglou E, Nikolakakis I, Botsoglou N. 2006. Effect of feeding rosemary and $\alpha$-tocopheryl acetate on hen performance and egg quality. The Journal of Poultry Science, 43: 143-149.

Gachkar L, Yadegari D, Rezaei MB, Taghizadeh M, Astaneh SA, Rasooli I. 2007. Chemical and biological characteristics of cuminum cyminum and Rosmarinus officinalis essential oils. Food Chemistry 102: 898-904.

Haugh RR. 1937. The Haugh Unit For Measuring Egg Quality. United States Egg Poultry Magazine, 43: 522-555.

Hernandez F, Madrid J, Garcia V, Orengo J, Megias MD. 2004. Influence of two plant extracts on broilers performance, digestibility and digestive organ size, Poultry Science, 4 (83): 169-174.

Hinton MH. 1988. Antibiotics, poultry production and public healt. World's Poultry Science, 44: 67-69.

Iqbal R, Aziz T, Sarfaraz I, Shabir R, Ansari MS, Malik MF, Saleem R, Zahra A, Mehwish S. 2013. Effect of vitamin E and selenium on 1mmunity, egg production and lever function in laying hens (HY-LINE W-98). Middle-East Journal of Scientific Research 14 (9): 1165-1170.

Jamroz D, Kamel C. 2002. Plant extracts enhance broyler performance, nonruminant nutriton antimicrobial agents and plant extracts on 1mmunity, health and performance. Journal of Animal Science, 80(1): 41(Abs). http://www.jtmtg.org/2002/abstracts/jnabs16.pdf. Erişim tarihi: 24.07.2013.

Kaya A, Turgut L. 2012. Yumurtacı tavuk rasyonlarına değişik oranlarda katılan adaçayı (Salvia officinalis), kekik (Thymbra spicata), nane (menthae piperitae) ekstraktları ile vitamin E'nin performans, yumurta kalitesi ve yumurta sarısı TBARS değerleri üzerine etkileri. Atatürk Üni. Ziraat Fak. Derg., 43(1): 49-58.
Kladna A, Michalska T, Berczyński P, Kruk I, Aboul-Enein HY. 2012. Evaluation of the antioxidant activity of tetracycline antibiotics in vitro. The Journal of Biological and Chemical Luminescence, 27: 249-255.

Korukluoğlu M, İrkin R, Sertel S. 2006. Salmonella ve Shigella Türlerinin gelişmesini engelleyen tıbbi bitkiler ve esansiyel yağlar, Gıda Dergisi 31(6): 319-324.

Layne E. 1957. Spectrophotometric and turbidimetric methods for measuring proteins. Methods in Enzymology, 10: 447-455.

Lopez-Bote CJ, Gray JI, Gomaa EA, Flegal CJ. 1998. Effect of dietary administration of oil extracts from rosemary and sage on lipid oxidation in broiler meat. British Poultry Science 39: 235-240.

Malayoğlu HB. 2010. Biberiyenin (Rosmarinus officinalis L.) antioksidan etkisi. Hayvansal Üretim, 51(2): 59-67.

Marrissey PA, Brandon S, Buckly DJ, Shehy PJA, Frigg M. 1997. Tissue content of alpha tocopherol and oxidative stability of broilers receiving dietary alpha tocopheryl acetate supplement for various periods pre slaughter. Bri. Poult. Science, 38 (1): 84-88.

Mathlouthi, N, Bouzaienne T, Oueslati I, Recoquillay F, Hamdi M, Urdaci M, Bergaoui R. 2012. Use of rosemary, oregano, and a commercial blend of essential oils in broiler chickens: In vitro antimicrobial activities and effects on growth performance. Journal Animal. Science, 90: 813-823.

Mitsopoulos I, Mitrakos P, Nikolakakis I, Nitas D, Dotas D. 2006. The effect of dietary rosemary dried leaves and annual stems and oregano essential oil on the performance and egg characterictics of laying hens. Epitheorese Zootehnikes Epistemes, 35: 61-72.

Newman KE. 2002. Antibiotic resistance is a reality novel tecniques for overcoming antibiotic resistance when using new growht promoters. nutritional biotechnology in the feed and food industries. Proceedings of Alltech's 18 th Annual Symposium, Nottingham, Nottingham University Pres,2002. pg. 98-106.

Radwan Nadia L, Hassan RA, Qota EM, Fayek HM. 2008. Effect of natural antioxidant on oxidative stability of eggs and productive and reproductive performance of laying hens. International Journal of Poultry Science, 7(2): 134-150.

Richheimer SL, Bernart MW, King GA, Kent MC, Bailey DT. 1996. Antioxidant activity of lipid soluble phenolic diterpenes from rosemary. J. Am. Oil. Chemisty Soc., 73: 507-514.

Rietjens IMCM, Marelle G, Boersma MG, Haan L, Spenkelink B, Awad HM, Cnubben NH P, Zanden JJ, Woude H, Alink GM, Koeman LH. 2002. The pro-oxidant chemistry of the natural antioxidants vitamin $\mathrm{C}$, vitamin $\mathrm{E}$, carotenoids and flavonoids. Environmental Toxicology and Pharmacology, 11: 321-333.

Şahin K, Şahin N, Önderci M. 2002. Vitamin E supplementation can alleviate negative effects of heat stress on egg production, egg quality, digestibility of nutrients and egg yolk mineral concentrations of japanese quails. Research in Veterinary Science, 73: 307-312.

Şimşek ÜG, Güler T, Çiftci M, Ertaş ON, Dalkılıç B. 2005. Esans yă̆ karışımının (kekik, karanfil ve anason) broylerlerde canlı ağırlık, karkas ve etlerin duyusal özellikleri üzerine etkisi. YYÜ. Vet. Fak. Dergisi, 16 (2): 1-5.

Taşkın A, Şahin A, Camcı Ö, Erener G. 2015. Kanatlılarda antistres uygulamalarında yeni yaklaşımlar. Türk Tarım - Gıda Bilim ve Teknoloji Dergisi, 3(7): 571-576.

Yeşilbağ D, Gezen SS, Biricik H, Meral Y. 2013. Effects of dietary rosemary and oregano volatile oil mixture on quail performance, egg traits and egg oxidative stability. British Poultry Science 54 (2): 231-237. 